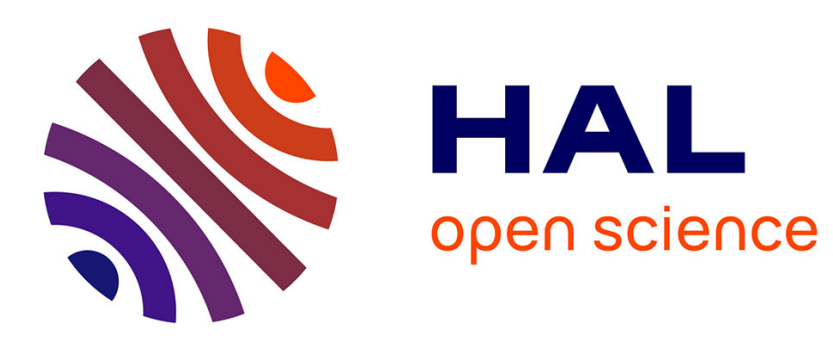

\title{
Alevism in the 1960s: Social Change and Mobilisation
} Elise Massicard

\section{To cite this version:}

Elise Massicard. Alevism in the 1960s: Social Change and Mobilisation. Alevis and Alevism, Transformed Identities, Isis, pp.109-135, 2005. halshs-00801120

\section{HAL Id: halshs-00801120 https://shs.hal.science/halshs-00801120}

Submitted on 4 Apr 2013

HAL is a multi-disciplinary open access archive for the deposit and dissemination of scientific research documents, whether they are published or not. The documents may come from teaching and research institutions in France or abroad, or from public or private research centers.
L'archive ouverte pluridisciplinaire HAL, est destinée au dépôt et à la diffusion de documents scientifiques de niveau recherche, publiés ou non, émanant des établissements d'enseignement et de recherche français ou étrangers, des laboratoires publics ou privés. 


\title{
Alevism in the 1960s: Social Change and Mobilisation
}

\author{
Elise Massicard
}

In: Hege Irene Markussen (ed.), Alevis and Alevism, Transformed Identities, Istanbul, Isis, 2005, p. 109-135.

\section{Introduction}

The decades following the Second World War were ones of crucial social change in Turkey. By the end of the 1950s, the social and political landscape of the country was transformed by demographic growth, expansion of education, development of industry, and massive migration to the cities and foreign countries. Settled mainly in the countryside, Alevis experienced this process of social change, which was characterised by urbanisation, social differentiation, the breaking down of former communities, and, more specifically, by the weakening of religious practice. Thus, in the 1960s they established closer contact with the "broader country" and partly lost their specificity.

However, the same years also witnessed the first Alevi public mobilisation of the Republican era, which initially had cultural dimensions centered around reviews and cultural events, and then political ones with the first "Alevi party", The Unity Party $(\mathrm{BP} / \mathrm{TBP})^{1}$. These developments may be considered as the indirect result of social change, and of the new conditions brought about by the multiparty system, political liberalisation and growing pluralism. Based on publications of the time ${ }^{2}$, interviews with people involved in this movement, and field work mainly in Sivas, this contribution first of all aims at giving a precise, descriptive account of these processes. Moreover, it tries to understand those who were the carriers and supporters of this movement. Finally, it attempts to provide an historical perspective, thus enabling comparisons with the contemporary Alevist ${ }^{3}$ movement.

\section{Migration and Social Change}

Kemalist reforms extended the control mechanisms of the State to previously almost autonomous regions. The integration of formerly peripheral regions into industrial production,

\footnotetext{
${ }^{1}$ Birlik Partisi (BP) created in 1966, later changed to TBP (Türkiye Birlik Partisi, Unity Party of Turkey).

${ }^{2}$ I want to express my gratitude to Michael Meeker for his very valuable comments on a previous version of this text. I also thank the editor and bookseller Adil Ali Atalay, his son, as well as the lawyer Hasan Gülşan and the researcher Ali Yaman for providing issues of these publications - which are not conserved in any public library in Istanbul cellars and private archives. Finally, I thank the lawyers Hasan Basri Özbey and Muslim Özcan for giving me important documentation on TBP from their private archives.

${ }^{3}$ I distinguish Aleviness (and Alevis), meaning the social phenomenon, from Alevism (and Alevists), which refers to the movement in the name of Aleviness, in the same way Islam and Islamism are distinguished.
} 
the construction of transport and communication networks, and the introduction of obligatory schooling progressively put an end to the spatial and social marginality of many Alevis, and brought about a growing interaction with the centre (Kehl-Bodrogi 1988 : 56).

This interaction further increased with migration. Because of "push" factors like rural overpopulation, fragmentation of land ownership and mechanisation brought by the Marshall plan, as well as "pull" factors such as the growing demand for industrial labour force, better quality of public services and the presence of educational opportunities in cities and towns, a large-scale rural depopulation began as early as the 1950s. Official authorities then considered urbanisation as a necessary step in the modernisation process, and strove to foster it. In 1950, about $25 \%$ of Turkey's population lived in urban areas, and this percentage increased to $42 \%$ in 1975 . In 1950 , only $8,3 \%$ of the population lived outside its birthplace, but this percentage reached 19,2\% in 1980 (Cerit 1986). Between 1965 and 1970, the urban growth rate exceeded $6 \%$, for a total population growth of $2,52 \%$. This migration was regionally differentiated; it was first very strong in the Black Sea region, then in central Anatolia at the end of the 1960s. Ankara, Istanbul and Izmir were the main destinations. One consequence of this rapid urbanisation was the emergence, in urban areas, of an illegal form of housing, the gecekondu. According to Karpat, at the beginning of the 1960s, 59,2\% of Ankara's population, 45\% of Istanbul's, and 33,4\% of Izmir's lived in gecekondu housing. Massively rural at that time, Alevis were strongly influenced by this migration wave. Alevis migrated relatively earlier and more massively than Sunnis, because they lived in disadvantaged regions (Karpat 1976: 260).

\section{Social Change and Social Differentiation}

There exists little data to account for the scale of the social upheavals that accompanied the migration. A journalist of the time, Fikret Otyam, has given an account of social differentiation in the Alevi village Karaözü of the Sivas province, which he visited in 1963. As early as 1928, the villagers had built a school by their own means, and the village's literacy rate amounted to $98 \%$ (whereas the national average was less than 50\%). In only fifteen years, the village had produced 347 civil servants, of which 132 were teachers educated in the Pazarören köy enstitüs $\ddot{u}^{4}$. The majority of those who had left the village (82 persons) were employed in the railways, but there were also 44 civil servants in the health sector, 37 officers, 24 policemen, and fifteen bank employees. There were more than one hundred 
students in the village as well. Karaözü hosted six associations and a co-operative of agricultural credit founded in 1952, which brought together six surrounding villages and supplied its 900 members with credits. In the 330 houses, there were no less than 400 radios and 100 sewing machines. In the five coffee-houses, one could find more than thirteen dailies and many magazines. Of course, we have to assume that this village was more flourishing than the average; as a matter of fact, its income came first of all from agricultural production (notably market gardening), but also from the seventeen grocers, the bakery, and even a hotel (Otyam 1982 [1963]: 124-126).

Obviously, this picture, which hardly hides the author's biased focus on development, did not hold true for all villages, and certainly not for all Alevi villages. Others had a more contentious or distanced relation to the state. An Alevi from the Sivas region confessed: "my family [...] did not want to let me study, for it did not trust the state and those things." (Interview December $2^{\text {nd }}$ 2000). However, this picture indicates some trends, like the importance some Alevis gave to education as a means of social mobility. As a consequence, the new employment opportunities released by the public sector, in the context of the development of the administration, gained a special importance as a source of jobs since there was hardly any Alevi bourgeoisie, craftsmen or merchants. As a matter of fact, employment in the public industries in Sivas (the railway yard and the cement factory) had been massively occupied by Alevis since their opening in the 1940s. Alevis' early integration into these jobs opened employment possibilities and facilities for their parents and friends as well ${ }^{5}$. Thus, strategies of social ascension through integration into the system, especially in civil service and factories, developed. Civil service, as well as liberal professions (doctors, lawyers, engineers) accessible through good school results, were therefore privileged by many Alevis. Of course, factors limiting the chances of socially disadvantaged children applied to Alevis as much as to anyone else. Nevertheless, the ambition to acquire positions of influence often incited Alevis to mobilise all the resources of the family in order to facilitate those who had success as early as primary school. Those who profited from this help then became lawyers, teachers, officers or even MPs, and as such, became resources for those who had helped them (Gökalp 1980: 759).

Moreover, as early as the late 1950s, Alevi craftsmen and merchants appeared in Sivas. The son of a Sunni grocer from Sivas remembers as follows:

\footnotetext{
${ }^{4}$ Created in the 1940s, village institutes had to train teachers for village schools. They were closed by the DP government in the early 1950s. See Öztürkmen 1998: 65-67.

5 Acquaintance was a widespread means of recruitment (Çoşkun 1995: 268-271).
} 
In the 1950s, Alevis began opening shops in Sivas. It was a new, unprecedented event. I remember, my father was a grocer at Sivas market, and one day, in the early 1960s, an Alevi came and opened a shop at the market (...). The guild did not know what to do; they consulted each other: would they apply the same rules to Alevis? (Interview September $29^{\text {th }}$ 1999).

Those Alevis who did not take advantage of education could rise by other means:

In 1965, as I was 30 years old, I came and settled in Sivas. I worked in a cafe, then, after two years, I opened my own cafe. Then I began to sell milled fittings for buildings. It's a good business, of quality and that pays well. (Interview December $2^{\text {nd }} 2000$ ).

This trend strengthened in the 1970s with the rise of remittances from relatives in Europe and the return of workers from Germany (Rittersberger-T1lıç 1998), allowing many Alevis to settle as merchants or independent craftsmen in the cities.

\section{Secularisation and Decline of Religious Practices}

Migration and social differentiation induced a weakening of Alevi religious practice, and, especially in urban environments, many Alevi rituals were abandoned. This may be explained in terms of different factors.

Village communities and the relations between dede and talip, which were the framework for religious practice, were dismantled by migration: "Before, we were conducting cem every winter in the village. But with migration, it was not possible any more, and we could only do it every third or fifth year. (Interview with a dede from Sivas, November $27^{\text {th }}$ 2000)". The dede had no means of continuing to supervise their emigrant flock all over the country or even in Europe. Because it became harder to earn their living through purely religious activities, they had to find other forms of work, and this undermined their religious authority. When the dede themselves migrated to cities, their communities became orphans and religious understanding declined.

Nevertheless, in some cases, village-like conditions were partly revived for some time by the migrants in the cities. Some evidence indicates that cem were held in the cities for some of the villagers on the occasion of the visit of a dede (Karpat 1976:128): "In the neighbourhood Altıntabak [Sivas], we did cem in secret. I remember a cem in 1963, we were afraid". In the big cities, some cem were held on a new community basis, the neighbourhood: 
When I was small, they did cem [in a gecekondu neighbourhood] in Ankara. Dede were doing them. [...] We had three dede there, one from Şarkışla, two from Divriği [districts of Sivas]. They did cem inside the neighbourhood. That lasted two or three years, then they stopped. Everyone was becoming isolated, they stopped the cem. In the vicinity there were all kinds of people, Sunnis, Çerkes [...] It stopped in 1980, we were afraid. (Interview with Alevi from Sivas, September $\left.16^{\text {th }} 1999\right)$.

The arrangements found in order to perpetuate the religious system were often temporary, and many dede stopped coming to the cities (Karpat 1976: 129). The institutions supposed to guarantee the survival of the community (like musahiplik) declined progressively with their raison d'être. In urban environments, Alevis could not lean on traditional religious structures any more; they had no infrastructure in the city. Therefore, they were particularly affected by secularisation. The ruptures induced by migration were even more radical abroad (Naess 1988: 182).

In addition, migration and social differentiation provoked the weakening of village hierarchies and other traditional structures, as well as a shift in social values (Mardin 1978). The functions of the dede as the judge and carrier of religious knowledge were henceforth executed by teachers and judges, ultimately having a profound affect on the dede's authority. Many (especially left-wing) youngsters and migrants even rejected this authority outright.

Although freedom of religion was guaranteed by the 1960 Constitution (art. 19), another factor that weakened the practice in urban environments was social pressure. With migration, Alevis came in closer contact with the surrounding society, and fear appears as a leitmotiv in the two previously cited testimonies. In Western Anatolian cities, there were assimilation trends, and even conversions. Alevi bourgeois and merchants from Senirkent, settled in Burdur, converted to Sunni Islam at the end of the 1940s (Öktem 2000). In the 1960s, Jean-Paul Roux also observed conversions of Tahtacı in southern Turkey as a way of acquiring upward social mobility (Roux 1964: 52-53). These topics, previously concealed by Alevis as well as by Sunnis, are now being discussed with regret and discomfort.

The weakening of religious practices due to social differentiation and migration occurred first in the cities, but also in the villages. Nevertheless, it is necessary to moderate this statement. First of all, practices weakened and disappeared gradually at different rhythms according to regions and social structures. Krisztina Kehl-Bodrogi dates the massive stop of cem ceremonies back to the 1960s (Kehl-Bodrogi, 1988: 70). In the same way, Peter Bumke underlines the depletion of ceremonies and religious practices since the 1960s in Tunceli, the 
loss of authority of religious leaders, and the gradual disappearance of musahiplik, notably because of the suspicious supervision by Turkish authorities (Bumke 1979: 542) ${ }^{6}$. Nevertheless, in other regions, practices were visibly abandoned later ${ }^{7}$. In some villages, the practice of cem was not interrupted until recently (Interview with Alevi from Karlı village, Sivas, $4^{\text {th }}$ December, 2000).

A process of secularisation in the meaning of "progressive autonomization of social sectors that escape the domination of religious meanings and institutions" was thus set in motion (Berger and Luckman 1967: 118). For the young generation, belief and its foundations remained an enigma, but it was often considered more as liberation than a loss (Väth 1993:216). These developments seem to fit quite well into a "modernization" process such as developmentalists conceive it: migration, social differentiation, secularisation, cultural assimilation, weakening of community practices, etc. However, other indicators seem to point towards different trends.

\section{Political Change}

Along with the various developments mentioned above, after years of living with a one-party system, Turkey finally gained a multiparty system in 1946. Henceforth, every party had to convince the voters, and these gained the power to give their voice or not. Thus, the Kemalist "people" (halk) became a political clientele (Güneş-Ayata 1994), and religion gained new importance as an electoral argument.

\section{Multiparti System : A New Political Logic}

The Democrat Party (DP) ${ }^{8}$, created in 1946, endangered the domination of The Republican People's Party $(\mathrm{CHP})^{9}$. It defended liberalism, equality, participation, a direct electoral system, and "the power to the people, not to the State", against the latter, considered to be centralist and bureaucratic. DP saw rural development as the key to an economic take-off, and therefore promised to provide resources to the peasants. It rapidly gained the support of the rural population. The elections of 1950 and, even more, of 1954, became a defeat for CHP, and a great victory for DP.

\footnotetext{
${ }^{6}$ In 1992, he states that Tunceli Alevis did not practice muharrem fasting any more, that aşure was prepared more and more rarely, that the taboo on the eating of hare was not always respected, and that the cem ceremony tended to disappear (Bumke 1992).

${ }^{7}$ David Shankland observed this process at the end of the 1980s (1993).

${ }^{8}$ Demokrat Partisi.

${ }^{9}$ Cumhurriyet Halk Partisi
} 
Contrary to the widespread opinion that Alevis have "always" supported CHP, many testimonies indicate Alevi support for DP in the $1950 \mathrm{~s}^{10}$. Massively rural at that time, and having greatly suffered from the oppression of the peasantry by CHP during The Second World War, Alevis were probably sensitive to agricultural matters (Schüler 1998: 264-265). The Alevi poet Ali İzzet Özkan interprets the victory of DP as liberation from tyranny:

\author{
The king died, the idol broke down \\ we have had enough of ignorance \\ the palace of tyranny fell down \\ we got rid of slavery \\ Democracy Messiah appeared \\ the tyrant's voice was cut \\ the call "Allah is big" \\ came down from the sky today ${ }^{11}$.
}

The transfer of the famous Alevi tribal leader Hüseyin Doğan — spiritual leader of A ğuiçen ocağl $_{2}$ and Malatya representative - from CHP to DP in 1951 is widely considered as an evidence of the Alevi support to DP. Although it can not be generalised into a model of "Alevi electoral behaviour", the vote in the Tunceli province also indicates a preference for the early DP: in 1950, DP won 58,7\% of the voices in Tunceli against 41,3\% for CHP. After that, CHP won steadily until 1965 (Schüler 1998: 262-263). In Sivas, most Alevis seem to have supported the DP at the 1950 and 1954 elections as well (Coşkun 1995: 271-272). There were even some dede families among the founders of the local branch of DP (Interview with an ocakzâde from Sivas, November $20^{\text {th }} 2000$ ). Some Alevis also were elected representatives of DP in Sivas (Interview with a local journalist in Sivas, December $6^{\text {th }} 2000$ ). In the first years, religion was probably not a determining factor of the vote, which was much more influenced by the peasant factor and the liberation of a felt authoritarianism.

\title{
Religion as a Political Issue
}

This, however, changed quite rapidly. Alevis constituted an important electorate in many regions. Thus, at the 1966 senatorial elections, all parties, and CHP especially, wooed Alevi

\footnotetext{
${ }^{10}$ Moreover, the fact that the liberal and conservative Nation Party (MP, Millet Partisi), won five seats in Kırşehir constituency in 1954 was attributed to the influence of the Bektashi order in this region (Reed 1954 : 281). But the popularity of Osman Bölükbaşı, the local party leader, has to be taken into account as well (Ahmad 1977: 371).
} 
voters (Mardin 1982: 186). But the accession of Aleviness to the status of a political issue could also represent a risk: in the mixed regions, it proved difficult to combine pro-Sunni and pro-Alevi discourses in a convincing manner. DP seems to have tried by using Aleviness as an electoral argument in Sivas (Unbehaun 2001: 3-4), and formulating different electoral speeches in Sunni and Alevi villages. While its politicians promised to construct Imam-Hatip schools in the Sunni villages, they recommended to Alevi villages: "let Sunni children go to the Imam-Hatip schools, while you educate your own children in modern schools" (Bozkurt 2000:??).

This double discourse being difficult to hold, right-wing parties rapidly adopted explicit Sunni discourses (Bozarslan 2002). It was at this moment that DP insisted on religious topics like reintroducing the call to prayer in Arabic, and opening mosques and Imam-Hatip high schools. It also began to woo brotherhoods, by calling the Nurcus to vote for DP, and by DP ministers expressing sympathy for the leaders of the Nurcu movement. Gradually, Sunni Islam was beginning to work as a system of clientelism. In fact, the multiparty system allowed increased freedom of expression and permitted open criticism of state secularism, as well as demands for a more central role of religion. Since the very beginning of the multiparty system, the popular demand for religious education had led CHP, under the pressure of the ballots just before the 1950 elections, to distance itself from the ban of Islam in public life, while introducing optional religious teaching in primary schools in 1949, opening a theology faculty in Ankara, and preparing the opening of Imam-Hatip schools in order to educate official imams (Mardin 1982 : $182 \mathrm{ff}$.).

While establishing new political dynamics, the multiparty system quickly led to the political use of religion. This may explain the departure of many Alevi voters from DP during the 1957 elections. Therefore, Alevi support for DP was often temporary. A few years later, the same poet Ali İzzet Özkan declaimed:

\footnotetext{
We thought that DP was a young girl

It proved ugly, perfidious, widow

It pretended to held its head high and have a pure face, we were mislead Its face has proven black, its head bald ${ }^{12}$.
}

\footnotetext{
${ }^{11}$ Kıral öldü put kırıldı/Halas olduk cehaletten/Zulmün sarayı yıkıldı/Kurtulduk biz ezaretten/Çıktı Mehdi Demokrasi/Zalimin kesildi sesi/Allahuekber nidası/Bugün indi semavattan/ (Başgöz, 1979: 102, quoted by Çoşkun 1995: 231).

${ }_{12}^{2}$ Demokrat Parti'yi taze kız sandık/Çırkın çıktı, kahpe çıktı, dul çıktı/Alnım açık, yüzüm ağ dedi kandık/Yüzü kara çıktı, Başı kel çıktı/ (Başgöz, 1979: 134, quoted by Çoşkun 1995: 231).
} 


\section{Political Liberalisation and the Beginning of an Identity Movement}

In the course of the 1950s, DP became more authoritarian. The government pestered the opposition by different means and monopolised political institutions (Landau 1974: 4). On May $27^{\text {th }} 1961$, a military coup overthrew DP. Many members of the party were judged for corruption, unconstitutional activities or high treason, and its leaders were executed. This coup was widely considered a liberal attempt to restore secularism and Kemalism. The National Unity Council withdrew from power, after having adopted a new Constitution which reaffirmed secularist principles and put secularisation measures taken by the early Republic under constitutional protection. The 1960 coup and the Constitution that followed in its wake were welcomed by a number of Alevis. Considered guilty of having supported Kemalism, Alevis had been partly held away from political life during the DP period. Sure of the support of the governing party, the Directorate of Religious Affairs (DIB) ${ }^{13}$ had even resumed some of the insulting Ottoman policies against Alevis (Bilici 1996: 288).

The will of the officers to bring about debates on topics considered until then as taboo, and to bring social reforms, brought about a new intellectual atmosphere (Mardin 1978: 233). This liberal Constitution recognised pluralism and the existence of social groups, and guaranteed the right to strike, as well as freedom of thought, expression, association and publication. Diverse social, political and/or religious forces could manifest themselves, encouraged by the development of the media. This liberal climate fostered political differentiation, itself encouraged by social differentiation and growing regional inequalities. The growing working class as well as the rural population gained combativeness through labour unions (Landau 1974, Vaner 1984: 82). In short, social and political boundaries became more pronounced, new social and associative movements appeared, and the parties diversified. The creation of Turkey Workers' Party (TIP) ${ }^{14}$ in 1961 and the Nationalist Movement Party (MHP) ${ }^{15}$ in 1969 — a continuation of the Republican Peasant National Party $(\mathrm{CKMP})^{16}$ founded in 1966 — put an end to the bipolarity dominating the $1950 \mathrm{~s}$.

\section{The Setting of the Alevi Issue on the Political Agenda}

Within this general framework, the "Alevi issue" appeared in public space for the first time. Alevis demanded that the principles of equality and brotherhood proclaimed by the Republic be applied to them as well, and their specificity admitted. For Sunnis, Aleviness became a

\footnotetext{
${ }_{13}^{13}$ Diyanet İşleri Başkanlığ

${ }^{14}$ Türkiye İş̧̧i Partisi.

${ }^{15}$ Milliyetçi Hareket Partisi.
} 
matter of concern, not only because it was perceived as heresy, but also because it seemed to constitute a favourable ground for leftist ideas and for "separatism". Although the official doctrine did not admit any segregation of the Alevis, in practice, politicians formulated more and more frequent warnings regarding a possible Alevi subversion (Dumont 1991: 161).

Paradoxically, official authorities themselves initiated this growing awareness. In 1963, on the order of Republic President Cemal Gürsel, Hayri Mumcuoğlu, State Secretary of the coalition government (AP-CHP) headed by İsmet İnönü, asked several Alevi dignitaries to express their opinions regarding the project of creating a mezhepler" dairesi, an office for "denominations" within DİB, so that "all Muslim communities be treated equally" (Özbey 1963: 6). The aim of this reform was to guarantee that all religious groups existing in Turkey would be represented within DİB. Immediately, the right-wing and religious press ${ }^{18}$ became offensive and accused the project of "bringing mum sönd $\ddot{u}^{19}$ ceremonies into the mosques" (Şener and İlknur 1995: 81). They denied the existence of Shiites in Turkey (Raif Ogan, Yeni Istanbul, $23^{\text {rd }}$ March, 1963), and refused the idea that Aleviness was a mezhep:

They have no religious books... All their beliefs are passed by word of mouth, and learned merely on rumours and traditions (Raif Ogan, Yeni İstanbul, 25 ${ }^{\text {th }}$ March, 1963).

Accepting legendary beliefs that pass from father to son, as if it was a precise and methodical mezhep [...] amounts to considering these superstitions as true and to legitimise them ! [...] Besides, Aleviness is not a mezhep, but a tarikat, and tarikats are forbidden by law...(Raif Ogan, Yeni İstanbul, $27^{\text {th }}$ March, 1963).

In response, approximately fifty Alevi students in Ankara prepared a declaration. But Kurdish and Turkish students would not agree to its title, with Kurdish Alevis rejecting the wording, "to the big Turkish nation" (Büyük Türk Ulusuna) and opting for "to all the people of Turkey" instead. In the end, only four Law students signed it:

\footnotetext{
${ }^{16}$ Cumhuriyetçi Köylü Millet Partisi.

${ }^{17}$ This word originally designates the four Islamic law schools. In Turkey, it often means "denominational group" and is used to designate Sunnis on the one side and Alevis on the other. For lack of a better term, it will be translated with "denomination".

${ }^{18}$ Daily newspapers like Milliyet and Cumhuriyet defended Alevis against the attacks in the religious newspapers Zafer and Adalet (Ankara-based AP newspaper). The most violent attacks came from the newspaper Sebil-ürReşad. As early as in 1950, this newspaper accused Alevis of being communists. A pamphlet of defence was published by a Kars MP as early as in 1951 (Erdoğan 1951).

19 "The candle went out". This expression designates incestuous and adulterous orgies that many non-Alevis believe and accuse Alevis of committing during cem ceremonies after having extinguished all lights.
} 


\begin{abstract}
It is obvious that practising separatism with sectarian differences among ethnically Turkish and Muslim citizens, instead of working for the unity of this country, only undermines national interests. [...] This community always got together around Atatürk during the national liberation war, worked in the service of national unity and remains the loyal defender of Kemalist principles ${ }^{20}$.
\end{abstract}

This declaration was widely broadcast in the newspapers and supported by many editorialists. A second statement was prepared by Alevi students and published in Türkiye on April $22^{\text {nd }}$, 1963; it was followed by another declaration signed by 347 students in Istanbul and published in Türkiye (why have you written "hareket" instead of Türkiye ?), May $1^{\text {st }} 1963$ as a reaction to a play entitled "Mum söndü" at the City Theatre ${ }^{21}$ (Şener and İlknur 1995 : 82). Panels on secularism were also organised (Özbey 1963). Famous progressive academics participated and defended the Alevi cause. Because of the strong protests it gave rise to, the project to create an office for mezhep was finally abandoned. The same year, a series on Aleviness was published in the newspaper Cumhuriyet, but it was interrupted by the military administration of Istanbul (Şahin 2001: 53).

\title{
Debating Aleviness: Justifications through Türklük and Services to the Country
}

In these public debates, Aleviness was legitimised by two kinds of arguments: on the one side by its Turkishness (Türklük), and on the other side by the services (hizmet) ${ }^{22}$ the Alevis were said to have performed for the nation through their devotion to Kemalism. I have not found a single exception to these arguments. No voice claimed the existence of Kurdish Alevis, even though the Kurdish nationalist movement developed and Kurdish-speaking Alevis like İzzettin Doğan or Seyfi Oktay actively participated in the debate on Aleviness. Moreover, arguments such as "there is room for Alevis in the Republic for there must be room for everyone" were nowhere to be found.

Besides, quite different definitions of Aleviness were expressed. It was unanimously considered as a religious phenomenon. However, its exact nature remained quite imprecise: some gave it the status of a religion (din), others of a mezhep, and others again of a

\footnotetext{
${ }^{20}$ Ali İlhan, Engin Dikmen, Mustafa Timisi, and Seyfi Oktay. Originating from a modest family, the latter was the first graduated student from his village in Malatya. He joined CHP in the 1960s; he was also a founding member and the first General Secretary of the Hacı Bektaş Association in Ankara. After 1980, he was elected three times as a MP from HP / SHP / CHP (from 1983 to 1987, and from 1991 to 1999). He was Minister of Justice from November 1991 to July 1994. (Interview with Seyfi Oktay, September 17 2001 ).

${ }^{21}$ Performance of the play was abandoned. When it was staged again in another theatre a few months later, the students attacked the theatre (Interview with a participant in this demonstration September $28^{\text {th }} 2000$ ).
} 
brotherhood (tarikat). For Ali Riza Ulusoy, Aleviness was neither a religion nor a brotherhood, but an Islamic vision, "islami görüş" (Özbey 1963: 43). The use of the term mezhep was quite imprecise as well. The idea that there were two mezhep (Sunni and Shiite) was often expressed and differences between the four Sunni schools of thought were blurred.

The main argument put forward by defenders of Aleviness to legitimise its place in the Republic was its presumed Turkishness. Like Cemal Özbey, Ali Riza Ulusoy thus spoke of "Alevi Turks", Alevi Türkler, and considered them "defenders of the national tradition and character". For him, Hacı Bektaş was not the founder of a brotherhood, but first of all the defender of Turkishness (Özbey 1963: 44-46): “Insofar as they represent Turkey's pure and immaculate Turkishness, accusing them [of practising mum söndü ceremonies] is a denial of, and an attack on, Turkishness" (Özbey 1963: 15-16). In the same way, İsmail Hakk1 Baltacıŏlu, a Sunni academic calling himself an "Action Turkist", aksiyon Türkçüsü, defended Alevism in following terms: "For the Tahtac1, the Kızılbaş, the Bektashis are nationalist Turks. [...] They love Ali as a Turk, and symbol of Turkishness" ${ }^{23}$. Newspapers defending the Alevis sanctified their Turkishness as well, leaning on the argument of bloodrelated brotherhood.: "Alevis and Bektashis, whom they provoke while calling them "Kızılbaş", are people of this country, they are Turkish, and they are Muslim"24.

The second argument legitimating the Alevis' place in the Republic was their defence of the country and the Kemalist principles. Their presumed role in the liberation war and their support of Atatürk were stressed again and again. This argument was opposed by some Sunni circles that accused Alevis of having supported the Kemalist occidentalist project merely as a means of defending their economic and social interests, thus denying them any merits as citizens (Laçiner 1984: 239). This stress on Turkish nationalism is interesting, since in the 1960s some middle-age Alevis in the villages were quite explicit about Aleviness as linked with Iran, saying that they would pray in a mosque if and when the Shah of Iran came to Turkey. This was a position which put them completely at odds with Turkish Nationalism, and it was not reflected in the public debates at all ${ }^{25}$.

Moreover, the argument of Turkey's unity was very much stressed ${ }^{26}$. Defenders of Alevis stigmatised the behaviour of religious-minded people as schismatic and dangerous for the national unity: Cemal Özbey accused the right of breaking "our unity and integrity",

\footnotetext{
${ }^{22}$ On the use of this word in Turkish political discourse, see Copeaux 1999.

${ }^{23}$ D. Malatya Gazetesi, $21^{\text {st }}$ July, 1965.

${ }^{24}$ F. Suad, Ulus Gazetesi, $24^{\text {th }}$ April, 1963 quoted in Özbey, 1963: 12-13.

${ }^{25}$ Conversation with Michael Meeker, August 2004.
} 
milli birlik ve bütünlüğ̈̈müzü, in order to provoke a war between mezheps. The press equally warned about the threat of fragmentation: it accused those who did not want to recognise freedom of religion of attempting to create divisions, and in this way becoming the enemies of the whole people ${ }^{27}$ : "At the very time when we need unity and national solidarity more than ever, the authors don't have the right to sow the seeds of discrimination among Muslims, among the people" (Özbey 1963:17). In addition, the religious-minded activists were called "fanatic opportunists", çıkarcl yobazlar, enemies and exploiters of religion who practice systematic provocation (Fikret Otyam in Özbey 1963: 39). Principles of equality and freedom of faith were highlighted, and the Alevis were praised as their defenders.

A last series of arguments referred to more general values, sometimes even to human rights. Defenders of Alevis presented them as linked to unity, but also to morality, human values, progressiveness and solidarity. In this call to universal values, the religiousminded camp was denounced as the enemy of civilisation (Ali Riza Ulusoy in Özbey 1963: 45).

\section{The Alevist Mobilization}

These debates and the general mobilisation led to the creation of Alevi associations in the big cities. The first one was The Hacıbektaş Tourism and Information Association, Hacıbektaş Turizm ve Tanıtma Derneği, in Ankara, founded by a member of the Ulusoy family, and active until 1970. The same year, The Cultural Association of Development and Assistance to Hacıbektaş, Hacıbektaş Kültür, Kalkınma ve Yardım Derneği, was created, also in Ankara, by another member of the Ulusoy family, Ali Celalettin. It soon consisted of seventeen branches all over Turkey. Peasants from surrounding Alevi villages participated, sometimes in large numbers, in the "Hacı Bektaş" evenings organised by these associations (Kaleli 2000: 17). This organisation also published the first Alevi magazine, Karahöyük, from July 1964 onwards, under the direction of another member of the Ulusoy family, Hüsrev Şir. In Istanbul, the first Hacı Bektaş Veli Cultural Association was created in 1963 by the lawyer Haydar Özdemir (who later became General Secretary of BP).

These associations were mainly involved in the organization of cultural evenings. For the first time, a public cem was organised by The Hacibektaş Tourism and Information Association in Ankara in December 1963, in which the most famous ozan (Aşık Veysel, Feyzullah Çınar and Mahsuni Şerif) participated. This cem caused a scandal. The

\footnotetext{
${ }^{26}$ Which recalls the emphasis on Turkishness and the stress on unity in the political discourse of the 1990s. See Massicard 2002.
} 
press referred to it as "Alevis doing propaganda for the left". Actually, this manifestation was supported by the left-wing TIP. Even proceedings were started against this manifestation, but in the end no one was arrested. In 1964, Bektashi circles, especially those linked with The Hacıbektaş Veli Culture and Tourism Association, Hacıbektaş Veli Kültür ve Turizm Derneği, set up an annual festival in the Central Anatolian town of Hacibektaş, the seat of the Hacibektaş tekke. Because of the interdiction of the tekke and brotherhoods' activities since 1925, this festival, copied from the Mevlevi one in Konya (established as early as 1953), was presented as a pure cultural manifestation, aiming to develop local tourism and to show the Bektashi heritage in a favourable light (Norton 1992). Nevertheless, as early as the opening ceremony, a military General, invited for the needs of the protocol, expressed suspicions towards Alevis (Kaleli 2000: 19). As a matter of fact, it became obvious that the festival served as a rallying point for Alevis and Bektashis, and that some "folkloric" spectacles played a mobilizing role (Dumont 1991: 162).

Another aspect of this Alevi turmoil was the creation of newspapers and reviews. The most famous was the political and cultural semi-monthly called Cem, created in 1966, devoted to the defence of the Alevi cause. Directed by Abidin Özgünay, this review joined the ranks of Kemalist orthodoxy. The newspaper's cover was decorated, in turn, with pious images representing Ali, the twelve imams, or Hacı Bektaş, and with portraits of Mustafa Kemal. An important part of the magazine was devoted to the presentation of various aspects of Alevi culture. The first issues contain a series on the relations between Aleviness and Shamanism. The magazine was equally full of articles on the lives of Ali, Hacı Bektaş and other sacred figures. In the section, "letters to the Editor", theological issues were sometimes discussed. Most of the time, however, the readers wrote to complain about insulting remarks or bad treatment inflicted on Alevis, especially by imams. The main part of the magazine was devoted to comments on current events and debates with various Sunni religious groups. In particular, the magazine contained many attacks against the Nurcu and Süleymancı brotherhoods, which it accused of infiltrating the religious apparatus and setting public opinion against Alevis. One of the themes frequently developed, especially by academics (including Sunnis), was that Alevis were full-fledged Turkish citizens, and that the existing juridical and constitutional equality should reflect this fact. Cem estimated that a strict application of secularist principles, associated with religious freedom, could alone provide a secure environment for Alevis (Dumont 1991: 163-164).

\footnotetext{
${ }^{27}$ F. E. Atay, Dünya Gazetesi, $23^{\text {rd }}$ April, 1963.
} 
Other Alevi publications appeared: the magazine Karahöyük in Hacıbektaş, published by Bektashis and some members of the Ulusoy family ${ }^{28}$, was released with its first issue on July $1^{\text {st }} 1964$; the weekly Ehlibeyt Yolu, The way of the Ehlibeyt - launched as an independent political newspaper defending Republicanism, freedom of thought, consciousness and equality —was published from 1966 onwards, and replaced by the semimonthly Ehlibeyt Yönü, The side of the Ehlibeyt, which was released at the end of 1968 and published until the coup of March $12^{\text {th }}, 1971$ (Yücel 1998: 61). It was introduced as an independent political newspaper, defending secularism and freedom of consciousness and thought, and showed a less Turkish nationalist tendency than the other newspapers (Interview with Hasan Gülşan, Istanbul, $16^{\text {th }}$ September 2001). In addition to these there are the semimonthly Halka Rehber, Guide to the People ${ }^{29}$, which ran from 1969 onwards and the semimonthly Gerçekler, Realities ${ }^{30}$, which ran from the mid-1970s onwards. All of these newspapers were published in Istanbul, with the exception of Ehlibeyt Yolu, which appears to have had a connection to Ankara. Even if their circulation was not very important, the movement was significant ${ }^{31}$.

The public debate on Aleviness spearheaded by these publications was reinforced by several events: In 1966, İbrahim Elmal1, the director of DİB, declared that Aleviness had disappeared, and the reaction of the Alevi public and media were so strong that he was forced to resign (Dumont 1991: 164-165). Sunni dignitaries replied with thinly veiled threats against Alevis (Kaleli 1990: 188). Some weeks later, in a memorandum on the "fight against harmful currents", the Chief of General Staff presented Alevis as instruments manipulated by international Communism. Again, the magazine Cem criticised him in virulent tones (Dumont 1991: 165).

Who were the carriers of this movement? First of all, the influence of the Ulusoy family $^{32}$, but also of Bektashi circles, was significant, especially in the creation of the Hacıbektaş festival. This rapprochement between Alevis and Bektashis was the fruit of convergent interests: some Alevi migrants used the association with Bektashism, which was

\footnotetext{
${ }^{28}$ More precisely, the "Tourism" association which organised the Hacibektaş festival.

${ }^{29}$ Launched as an "independent political newspaper defending secularism and freedom of consciousness, for God and the people".

${ }^{30}$ Launced as a "Current, literary, religious newspaper".

${ }^{31}$ Since I could not find the complete collections of these newspapers, it remains difficult to know until when they were published, if they followed one another - as their approximate publication periods seem to indicate or if they were published simultaneously.

32 According to Mustafa Timisi, the members of the Ulusoy family did not launch the mobilisation. At the beginning, they had to stay in the background because of the watch on them by the authorities. When the movement developed, different members could then become more active. Interview with Mustafa Timisi, Ankara, $6^{\text {th }}$ December, 2000.
} 
less taboo than Aleviness at the time, to integrate in a new urban environment (Karpat 1976: 128) and to facilitate contacts with an established urban elite (Interview with Seyfi Oktay, Ankara, $17^{\text {th }}$ September, 2001). This rapprochement probably permitted some Bektashis to find popular and massive grassroots. Aside from this, two groups seem to have been particularly active in BP: on the one hand, there was an elite, urbanised decades earlier ${ }^{33}$, in which the big families played an important role - these were the ones responsible for publishing the newspapers and reviews); on the other hand, there were the first Alevi students - the second generation of migration, and the first ones to benefit from access to the superior educational system. Like Kurdish and Islamic movements, Alevist mobilisation was generated by the double processes of urbanisation and mass education. It appeared in the cities, where students, intellectuals, and later, migrant workers experienced their "otherness" in relation to the surrounding population, as well as occasional incidents of discrimination.

Who did these public debates and initiatives around Aleviness reach? Associations probably gathered only a small minority of Alevis. However, in some villages, there were also attempts to codify a written Aleviness, leaning on principles of beliefs and practices. These attempts were carried out by individuals in their 40s and 50s, who were not necessarily ocakzade. This shows that the villages were neither intellectually isolated, nor passive ${ }^{34}$.

\section{The Unity Party (BP/TBP)}

\section{The Creation of a "Denominational" Party?}

In this climate of turmoil, several Alevis were attacked by Sunnis in Ortaca (near Muğla) in July 1966, under the pretext that they had burned the mosque and destroyed the minaret ${ }^{35}$. After this event, different initiatives aiming to politically organise Alevis appeared. The creation of the Unity Party (BP/TBP) coincided with the launching of the magazine Cem, which supported the idea that Alevis should gain influence through their own party and further covered the formation of the party. The publisher and owner of the magazine also had a direct link with the party, being the president of its Istanbul branch.

\footnotetext{
33 Among the founding members of Hacı Bektaş Kültür, Kalkınma ve Yardım Derneği, there was a hotel manager, two businessmen, a journalist and printer, but only one farmer (Kaleli, 2000: 19).

${ }^{34}$ Conversation with Michael Meeker, August 2004.

${ }^{35}$ For a more precise description of this event, see Ehlibeyt Yolu, $27^{\text {th }}$ July 1966 and Kaleli 2000: $97 \mathrm{ff}$.
} 
The party was created on October $17^{\text {th }}$, 1966 by people "without political experience" (Teziç, 1976: 336), its President being a retired general ${ }^{36}$, and its General Secretary being the lawyer Cemal Özbey. Among the founders ${ }^{37}$, was also the Post-nişin of the time, the lawyer Feyzullah Ulusoy. He was a member of the party's board until withdrawing in 1967, accusing the other members of being unable to manage a political party $^{38}$. The Ulusoy family supported this initiative: In 1967, Kâzım Ulusoy, then MP of the right-wing Nation Party, Millet Partisi, joined BP along with his colleague, the Adana MP Hüseyin Balan. Three members of the family were elected MPs of the party in the 1969 elections. The founders therefore represented what might be called an Alevi "elite".

Some observers explained the creation of this party with social and economical arguments: Alevi craftsmen and merchants from Anatolia could thereby oppose the development of big, overwhelmingly Sunni, employers (Ahmad and Turgay-Ahmad 1976: 318). Defining itself as Kemalist, secularist and progressive, refusing conflicts of class and confession, this party advocated a planned economy controlled by the state, and it promised the redistribution of land (Teziç 1976: 335-336). Nevertheless, the explanation emphasizing the economic interests of Alevi merchants from Anatolia seems exaggerated, since the party's first initiators were located in Ankara and Istanbul, even though they were soon followed by people in Anatolia. An alternate explanation attributes the founding of the party to the marginalization of Alevis in CHP during the 1960s, and notably, in the 1965 elections (Interviews with Mustafa Timisi, Ankara, $6^{\text {th }}$ December 2000 and with Seyfi Oktay, Ankara, $17^{\text {th }}$ September, 2001).

For Feroz Ahmad and Bedia Turgay-Ahmad, BP represented the defence of Secularism against the religious camp (Ahmad and Turgay-Ahmad 1976: 318). Secularism and religion were in the centre of the social and political debate of the 1960s. Moreover, the use of "denominational" arguments by parties had changed the public place of religion. The creation of an Alevi party was also a reaction against what was considered the "exploitation of religion for political ends". Tİ would have been one of the first parties to openly use "denominational" arguments:

\footnotetext{
${ }^{36}$ Hasan Tahsin Berkman, born in 1904, from Çorum, retired since 1958.

${ }^{37}$ The founding members were: Cemal Özbey, lawyer from Arguvan (Malatya province) was the General Secretary, and Hüseyin Günal (building contractor) and Tahsin Tosun Sevinç (trade-unionist) his assistants. Among the other were also Feyzullah Ulusoy, Salim Delikanlı and Hüseyin Eren (retired colonels), Mustafa Geygel (building contractor), Mehmet Güner and Mehmet Ali Egeli (economists), Hüseyin Erkanlı and Faruk Ergünsoy (lawyers), Mustafa Topal (doctor), Arif Kemal Eroğlu and İbrahim Zerze (workers), and Hüseyin Dedekargınoğlu (printer) (Cumhuriyet, $18^{\text {th }}$ October 1966 ; Kaleli, 2000: 33).

${ }^{38}$ Cem n ${ }^{\circ} 29$, October 1993, p. 27-28.
} 
TIP has now discovered this fertile issue. They have been trying to make political capital out of the Sunni / Alevi division by fostering a political connection between the freethinking urban supporters of their party and the traditional mystic Alevi communities. [...] It is no doubt in order to forge more effective links with the Alevi community that the annual convention of this party in the winter of 1966 was held in the province of Malatya (Yalman 1969: 59-60).

Feyzullah Ulusoy explains retrospectively that, for the 1969 elections, TiP advertised in Alevi villages by presenting itself as an Alevi party and by putting forward the fact that Mehmet Ali Aybar, the leader of the party, was ocakzâde. That is why he became MP in the Yozgat province: "We were accused of being Klzllbaş, let's try to avoid being accused of being Communists. I thought that if the Alevis saw my name, they would understand which the true Alevi party was" ${ }^{\prime 39}$.

Nevertheless, it would be an exaggeration to interpret the creation of BP as a reaction to political Islam. Of course, AP had been in power since 1965, and Islam remained, with anti-Communism, a major instrument in the hands of the right against the growing strength of the left. Moreover, taking advantage of the permissive attitude of the AP government, religious-minded associations as well as Koranic schools were on the increase. Nevertheless, Alevis politically organised themselves before the Sunnis, and the creation of BP may well have encouraged initiatives aimed at organizing Sunni Islam politically. In 1969 in Sivas, after BP had entered the lists, the mufti of Sivas was placed on the AP list, thus allowing it to present itself as a representative of Sunnis. As in 1965, the AP and the CHP each obtained four seats, but the explicit use of the "denominational" variable had changed the game. At the national level, new parties created at the end of the 1960s questioned AP's control of the right and used religion freely as a political argument: Firstly, the nationalist MHP, founded in 1969 by the colonel Alpaslan Türkeş, had success in religiously mixed areas. Secondly, the Islamic-minded Party of National Order, MNP, Millî Nizâm Partisi, was created just before the 1969 elections under the sponsorship of AP. Very soon, however, refusing to play the role that AP had foreseen, it became a political formation on its own in 1970. Refusing to appear as a "denominational" party, it stressed that " $99 \%$ of the people is Muslim" (Laçiner 1984: 243). It was closed down in 1971 after the coup, and reorganised in 1972 under the name of The National Salvation Party, MSP, Milli Selamet Partisi.

\footnotetext{
${ }^{39}$ Cem 29, October 1993, p. 27.
} 


\section{The Turn to the Left}

As early as its creation, BP seemed torn by the question of whether it should be an open "denominational" party (i.e., assume its "denominational" dimension), or a progressive, Kemalist party instead, which over the course of the 1970s gradually meant a leftist party. This tension became apparent through the competition between the two main wings: the "religious" one, led by Cemal Özbey and Hüseyin Bazlan, and the more "political” one, led by Mustafa Timisi. Timisi, who was about thirty years old at that time, and lived in an Ankara gecekondu, explained to me that that the rival wing, profiting from his absence, had created the party under a religious banner and taken for its emblem a lion surrounded by twelve stars, a symbolic representation of Ali and the Twelve Imams :

\footnotetext{
Unfortunately, another group - of Alevi origin, completely of Alevi origin - while in my own initiative, there were also friends from Sunni origin. And there, Alevi motives had not been put forward. Another group therefore, under the leadership of Cemal Özbey [...], had taken an initiative. In order not to underestimate their work and not to put them in the shade, we had integrated them in our work group, a little bit with the idea of not letting them do stupid things, to keep them under control [he laughs]. But unfortunately, before the creation, before our work was institutionalised, before we could arrive to a certain point, with their friends they founded TBP separately. I, at that very moment, I was not there, I was not in Ankara. That's how the BP was founded [...] A group, despite us, a group within us, taking the initiative, put these twelve stars with the lion in the middle [...] I was not informed about it. [...] Of course, with such a beginning, it appeared as Alevis' own movement (Interview with Mustafa Timisi, Ankara, 6th December, 2000).
}

As early as March $18^{\text {th }}$, 1967, Hüseyin Balan was elected General Secretary. Even if, in their public declarations, the founders adamantly refused to be labeled Alevi, certain formulations of the manifesto showed the importance given to the religious issue, and, a fortiori, an Alevi orientation - even without mentioning confession explicitly. The party advocated:

[...] the protection of freedom of consciousness, of faith and opinion for all; tolerance of all sorts of religious worship and ceremony provided they do not threaten public order and are not conflicting with the general moral representations nor to the laws that protect them; no one shall be obliged to participate in worship or religious services, or to reveal its religious convictions; and no one shall be condemned for his beliefs and religious representations (The political program of BP, Birlik Partisi Programı, art. 9).

Because of the need "to ensure equality of rights and religious equality, as well as to avoid coercion", religious education had to inculcate the students with secularist principles such as 
Revolutionarism, Reformism, progressiveness, unity, solidarity and tolerance. In this view, religious education, like worship itself, should not be monopolised by a single religion or a given faith (Birlik Partisi Programı, art. 15; Ahmad and Turgay-Ahmad 1976: 336).

In 1969, in its first elections, BP gained 2,8\% of the valid votes and eight MPs, of which three came from the Ulusoy family ${ }^{40}$. This result was not very spectacular ${ }^{41}$, but superior to that of other new, small formations present on the political scene at that time for example, the MHP. The BP showed much regionally differentiated results (Schüler 1998: 267-269). It achieved most success in central and eastern Anatolia, and notably in religiously "mixed" regions, with a record of $16,7 \%$ in the Sivas province (Özbudun 1976: 110), probably because of the popularity of Mustafa Timisi in his region of origin.

In 1969, during its second congress, BP was renamed The Unity Party of Turkey, TBP, Türkiye Birlik Partisi, in order to put an end to the rumours which accused it of working for a division of Turkey, or on behalf of Iranian interests (Yücel 1998: 66). Beside this, internal tensions became more virulent. After controversial debates, the Sivas representative Mustafa Timisi was finally elected as the General Secretary (Interview with Abidin Özgűnay, Istanbul, 25th October, 2000). He wanted to transform TBP into a "more radical and more dynamic" party (Turkish press of $24^{\text {th }}$ and $25^{\text {th }}$ November 1969 , quoted by Ahmad and Turgay-Ahmad 1976: 379). The third congress in 1970 was again characterised by the tension between the two wings, but Mustafa Timisi was still re-elected.

While there was no clear majority in the Parliament, TBP, even with few representatives, gained a strategic position. In 1970, five of its representatives ${ }^{42}$ decided to support the conservative liberal government of Süleyman Demirel, leader of AP. The strong reaction of the grassroots led to the exclusion of these representatives from the party ${ }^{43}$, and finally to its shift to the left. Later publications of TBP (like TBP 1978: $17 \mathrm{f}$ ) indicate that it wanted to erase its widespread Alevi image. For Mustafa Timisi,

[I]t is true that those voting for the BP are especially Alevis. But it is not a consequence of the denominational factor. It is a result of the sincere Kemalist secularist vision which is at the foundation of the party (Teziç 1976: 336).

\footnotetext{
${ }^{40}$ The MPs were Hüseyin Balan (Ankara), Haydar Özdemir (Istanbul), Kazım Ulusoy (Çorum), Ali Naki Ulusoy (Amasya), Yusuf Ulusoy (Tokat), Sami İlhan (Malatya), Mustafa Timisi and Hüseyin Çınar (Sivas).

${ }^{41}$ It is important to point out that the party did not present candidates in many provinces, including provinces with a considerable Alevi population, like Giresun or Gümüşhane (Karpat 1975: 116).

${ }^{42}$ Kazım Ulusoy, Ali Naki Ulusoy, Yusuf Ulusoy, Hüseyin Balan, and Hüseyin Çınar.

${ }^{43}$ See the book published by the party on this issue: Birlik Partisi n.d.
} 
Henceforth, the party presented itself as a revolutionary, anti-fascist party of the working class, and positioned itself on the left of CHP, in competition with TiP, which was closed down during the 1971 coup (Schüler 1998 : 266).

In 1973, the electoral manifesto clearly indicated this shift to the left with slogans such as: "Long live a freer, more independent and more democratic Turkey !”, or by materialist issues like the liberation of peasants, workers and the "exploited". Being antiimperialist, the party advocated the end of the relations with NATO and the Common Market. It resumed the six principles of the CHP, with some interpretative differences, and added some leftist principles as well ${ }^{44}$.

Even after this leftist shift TBP did not really abandon claims relating to religious matters. On the contrary, it attempted to reconcile religious beliefs and socialist principles:

For TBP, Socialism is not a rigid and one-dimensional thought. It accepts the laws of scientific Socialism and other social researches, religious and humanists principles, customs and traditions. That is why TBP respects religious beliefs and materialist philosophies in the same manner. It considers differences coming from political ideas and religious beliefs as an individual problem and wants the state to equally respect these differences. [...] All big religions (for example the Muslim religion) accept the necessity of social transformations. Socialism and religion unite in love of the people. A dispute between Socialism based on ethical principles, and religious beliefs is therefore impossible, provided that religion does not become a means to provoke differences, to oppress, or to exploit the laborious masses. [...] There is no contradiction between religion and Socialism. A believer can be a socialist too. But religion is a matter of the communities, that is why the Directorate of Religious Affairs does not have any place in a secularist Republic (Türkiye Birlik Partisi 1973: 31).

Probably, a Kemalist and leftist centre coexisted with many more religious-minded members within the party ${ }^{45}$. Moreover, TBP used religious arguments especially to criticise its opponents: "The party considers the multiplication of anachronistic educational establishments, practised in spite of the secularist principle and the spirit of Kemalism to educate enlightened men of religion, as dangerous for the future of the people". It criticised the religious politics of the right-wing parties by accusing them of "exploiting outdated, scholastic and fanatical ideas" (Türkiye Birlik Partisi 1973: 51).

\footnotetext{
${ }^{44}$ The principles added by the TBP are: socialism (toplumculuk), democracy, independence, libertarism (özgürlükcülük), equality and patriotism. Türkiye Birlik Partisi, 1973: 12-30.

${ }^{45}$ Interview with a former member of the TBP's assembly, Ankara, 23th November, 2000.
} 
This slide to the left permitted TBP to take advantage of the absence of any other socialist party in the 1973 elections. It allied with a group of socialists, and the former TIP leader, Mehmet Ali Aybar, was on the top of TBP's list in Istanbul. But the party had already lost a part of its credibility. In 1973, it obtained only 1,1\% of the votes, and one single representative, Mustafa Timisi. He has retrospectively explained TBP's decline by the fact that the idea of an Alevi party was not accepted, and that the CHP, headed by Bülent Ecevit, who had succeeded İnönü, appropriated the claims and aims of TBP, but with much more credibility (Timisi 1988: 15). As a matter of fact, at the beginning of the 1970s, the CHP adopted a "left of the centre" position : it added socialist values to Kemalist principles and put the problems of migrants and urban workers to the fore. CHP then achieved great success, notably in Central and Eastern Anatolia (with an increase of 7,7\% in comparison with 1969), which was sometimes interpreted as the return of the 1969 TBP-voters to CHP (Özbudun 1976 : 215). In the 1970s, CHP became the most important party in the urban centres. At the 1975 senatorial by-elections, TBP again lost votes, and disappeared completely from Parliament after the 1977 elections, where it obtained only $0,4 \%$ of the votes. Before that election, the General Secretary and several members of the General Assembly resigned from TBP to join CHP, considering that a union with CHP was the only solution at that time ${ }^{46}$.

Therefore, TBP did not succeed in gathering Alevi votes. As TBP was "an organisation cutting vertically through social classes, [it was a] representative of the ideology of a denominational community" (Sencer 1971: 343), and the Alevis were doubtless too socially and economically differentiated to gather in a party whose program had for single originality an Alevi symbolic. In addition to internal discord, this failure also had external reasons like the competition of more credible parties in the same niche. The fiasco of TBP indicates that there was no room, in the 1970 s, for a party devoted - even implicitly - to the defence of a "denominational" minority. With the growing correspondence between Sunni Islam and right-wing Nationalism, young Alevis moved gradually towards the secular left and sometimes actively turned against the dede and religious practices. Aleviness could not attain the place occupied by orthodox Islam in political discourse, and the Alevis did not succeed in transforming their religious system into a mobilising political ideology (Bayart 1982 : 114).

\footnotetext{
${ }^{46}$ Interview with a former member of the TBP's assembly, Ankara, 23th November, 2000.
} 


\section{Conclusion}

In the 1960s, in the course of urban migration, Alevis experimented with a radical process of social and religious change characterized by the breaking down of former communities and the loss of religious practice. They sociologically "integrated the broader country" and partly lost their specificity.

However, the same years also witnessed the first Alevi public mobilization of the Republican era, which had both cultural and political dimensions. Religion became a political issue, and the "denominational" variable became a determinant element of political space. At the same time, however, the worker and student movements of the 1960s indicated growing horizontal mobilisation. In these conditions, can we speak about the formation of an Alevi political space ? Many analysts assert that Alevis were by and large in favour of CHP's opinions which, in the 1960s, progressively turned from Kemalism to Socialism. Moreover, it is generally admitted that a good part of the voices that permitted TiP to obtain fifteen seats at the 1965 elections came from Alevis. In the 1969 elections, in Tunceli, TIP obtained much better results $(16,8 \%$ of the votes) than TBP $(6,9 \%)$. TBP was influential in the same region as TIP, which some observers explain by the numerical importance of Alevis (Özbudun 1976: 110). Thus, the 1960s show the emergence of an Alevi political space, but one that was not monopolised by a single political party. 


\section{References}

Ahmad, Feroz. 1977. The Turkish Experiment in Democracy, 1950-1975. London: C. Hurst for the Royal Institute of International Affairs.

Ahmad, Feroz, and Bedia Turgay-Ahmad. 1976. Türkiye'de çok partili politikanın açılamalı kronolojisi, 1945-1971. Istanbul: Bilgi.

Başgöz, İlhan. 1979. Aşık Ali İzzet Özkan. Ankara: Türkiye İş Bankası Kültür Yayınları.

Bayart, Jean-François. 1982. La question Alevî dans la Turquie moderne. In L'islam et l'Etat dans le monde aujourd'hui, p. 109-120. Edited by Olivier Carré. Paris: Presses Universitaires de France.

Berger Peter L., and Thomas Luckmann. 1967. Aspects sociologiques du pluralisme. Archives de sociologie des religions, 23: 117-127.

Bilici, Faruk. 1996. Les alévis, alliés naturels du kémalisme en Turquie. In Islam et laïcité : approches globales et régionales, p. 281-298. Edited by Michel Bozdémir. Paris: L'Harmattan.

Birlik Partisi. n.d.. Beş yoldüşkünü. Istanbul: TIPO.

Bozarslan, Hamit. 2002. L'alévisme et l'impossible équation du nationalisme en Turquie. In Nationalismes en mutation en Méditerranée orientale. Edited by Alain Dieckhoff and Riva Kastoryano. Paris: Editions du CNRS.

Bozkurt, Fuat. 2000. Çă̆daşlaşma sürecinde Alevilik, Istanbul: Doğan Kitapçılık.

Bumke, Peter J.. 1979. Kızılbaş-Kurden in Dersim (Tunceli, Türkei): Marginalität und Häresie. Anthropos 74: 530-548.

Bumke, Peter J.. 1992. Quelques aspects de l'organisation des Alévis Kurdes. Revue des Etudes Islamiques LX:109-116.

Cerit, Sevil. 1986. Türkiye'de İller arası göçler. Turkish Population Studies 8:81-103.

Copeaux, Etienne. 1999. Linguistique et discours historique : premier bilan et piste de recherche. Etudes turques et ottomanes 8:7-19.

Çoşkun, Zeki. 1995. Aleviler, Sünniler, ve öteki Sivas. Istanbul: İletişim.

Dumont, Paul. 1991. Le poids de l'alévisme dans la Turquie d'aujourd'hui. Turcica XXIXXIII:155-172.

Erdoğan, Fahri. 1951. Sekiz Milyonluk Alevi Türklerine Kızll Komünist Damgasını Vuran Şebilürreşatçılara cevap ve bektaşilik. Ankara: Emek.

Gokalp, Altan. 1980. Une minorité chiite en Anatolie : les Alevî. Annales 35 (3-4):748-763.

Güneş-Ayata, Ayşe. 1994. Roots and trends of clientelism in Turkey. In Democracy, Clientelism and Civil Society, p. 51-63. Edited by Ayşe Güneş-Ayata and Luis Roniger. Boulder: Rienner.

Kaleli, Lütfi. 1990. Kimliğini Haykıran Alevilik. Istanbul: Habora.

Kaleli, Lütfi. 2000. Alevi kimliği ve Alevi örgütlenmeleri. Istanbul: Can.

Karpat, Kemal. 1975. The politics of transition: political attitudes and party affiliation in Turkish shantytowns. In Political Participation in Turkey, p. 89-119. Edited by Engin D. Akarlı and Gabriel Ben Dor. Istanbul: Boğazici Üniversitesi. 
Karpat, Kemal. 1976. The Gecekondu, Rural Migration and Urbanization. Cambridge: Cambridge University Press.

Kehl-Bodrogi, Krisztina. 1988. Die Klzllbaş/Aleviten, eine Glaubensgemeinschaft in Anatolien. Berlin: Klaus Schwarz.

Laçiner, Ömer. 1984. Der Konflikt zwischen Sunniten und Aleviten in der Türkei. In Islam und Politik in der Türkei, p. 233-254. Edited by Jochen Blaschke and Martin van Bruinessen. Berlin: Parabolis.

Landau, Jacob M.. 1974. Radical politics in modern Turkey. Leiden: Brill.

Mardin, Şerif. 1978. Youth and violence in Turkey. Archives Européennes de sociologie XIX: 229-254.

Mardin, Şerif. 1982. Turkey: Islam and Westernization. In Religions and Societies: Asia and the Middle East, p. 171-198. Edited by Carlo Caldarola. New York: Mouton.

Massicard, Elise. 2002. Les alévis et le discours de l'unité en Turquie depuis les années 1980. In Aspects of political language in Turkey (19th-20th centuries), p. 117-136. Edited by HansLukas Kieser. Istanbul: Isis.

Naess, Ragnar. 1988. Being an Alevi Muslim in South-Western Anatolia and in Norway: The Impact of Migration on a heterodox Turkish Community. In The New Islamic Presence in Western Europe, p. 174-195. Edited by Tomas Gerholm and Yngve Georg. Lithman. London: Mansell.

Norton, John. 1992.,"The development of the annual festival at Hacibektaş, 1964-1985; Revue des Etudes Islamiques LX:187-196.

Otyam, Fikret. 1982 [1963]. Hû Dost, Ankara: Dayanışma Basımevi.

Öktem, Alper. 2000. Burdur'a yerleşmiş Senirkent Alevileri". Tarih ve Toplum 196: 43-49.

Özbey, Cemal. 1963. Alevîlik üzerine tartışmalar. Ankara: Emek Basımevi.

Özbudun, Ergun. 1976. Social Change and Political Participation in Turkey. Princeton: Princeton University Press.

Öztürkmen, Arzu. 1998. Türkiye’de Folklor ve Milliyetçilik, Istanbul: İletişim.

Reed, Howard A.. 1954. Revival of Islam in Secular Turkey. Middle East Journal 8(3): 267282.

Rittersberger-T1lıç, Helga. 1998. Vom Gastarbeiter zum Deutschler, Die Rückkehrergemeinschaft in einer türkischen Kleinstadt. Potsdam: Verlag für BerlinBrandenburg.

Roux, Jean-Paul, and Kemal Özbayr1. 1964. Quelques notes sur la religion des Tahtac1 nomades bûcherons de la Turquie méridionale. Revue des Etudes Islamiques XXXII: 45-86.

Schüler, Harald. 1998. Die türkischen Parteien und ihre Mitglieder. Hambourg, OrientInstitut.

Sencer, Muzaffer. 1971. Türkiye'de Siyasal Partilerin Sosyal Temelleri, Istanbul: Gençiş.

Shankland, David. 1993. Alevi and Sunni in Rural Anatolia: Diverse Paths of Change. In Culture and Economy : Changes in Turkish Villages, p. 46-64. Edited by Paul Stirling. Huntingdon: The Eothen Press.

Soysal, İlhami. 1983. Mezhepler/Tarikatlar. Cumhuriyet Dönemi Türkiye Ansiklopedisi, vol. 5, p. 1364-1378. Istanbul: İletişim. 
Şahin, Şehriban. 2001. The Alevi Movement. Transformation from Secret Oral to Public Written Culture in National and Transnational Social Spaces. Ph.D. diss., New School for Social Research.

Şener, Cemal, and Miyase İlknur. 1995. Alevilik ve Şeriat. Istanbul: Ant.

Teziç, Erdoğan. 1976. 100 soruda siyasi partiler (Partilerin hukukî rejimi ve Türkiye'de partiler). Istanbul: Gerçek.

Timisi, Mustafa. 1988. Aleviler, Doğru, Güzel, Güçlü Olanı Destekler.... Tempo 37, August 14,15 .

Türkiye Birlik Partisi. 1973. 1973 Seçim Bildirgesi, Ankara.

Türkiye Birlik Partisi, 1978. Türkiye Birlik Partisi 1966-1978. Istanbul: Nurdoğan Matbaasi.

Unbehaun, Horst. 2001. Die Regionalorganisation der CHP bis 1950 nach Parteidokumenten. Paper presented at the $28^{\text {th }}$ Congress of German Orientalists, March 26, Bamberg, Germany.

Vaner, Semih. 1984. Violence politique et terrorismes en Turquie. Esprit 94-95: 79-104.

Väth, Gerhard. 1993. Zur Diskussion über das Alevitum. Zeitschrift für Türkei-Studien 6 (2): 211-222.

Yalman, Nur. 1969. Islamic reform and the mystic tradition in eastern Turkey. Archives Européennes de Sociologie X: 41-60.

Yücel, Hakan. 1998. L'organisation alévie-bektachie, Master thesis, Marmara Üniversitesi. 